Journal of Applied Pharmaceutical Science Vol. 7 (04), pp. 142-148, April, 2017

Available online at http://www.japsonline.com

DOI: $10.7324 / \mathrm{JAPS} .2017 .70421$

ISSN 2231-3354 (cc) BY-NC-sA

\title{
Development of Natural Preservative from Silene vulgaris Extract in Topical Formulation under a Challenge Test and its Stability Study
}

\author{
Smahane BOUKHIRA ${ }^{\mathrm{a}^{*}}$, Mounyr BALOUIRI ${ }^{\mathrm{b}}$, Latifa El MANSOURI ${ }^{\mathrm{a}}$, Amal El HAMSAS El YOUBI ${ }^{\mathrm{a}}$, Mouna \\ BOUARFA $^{\mathrm{a}}$, Siham LEBTAR ${ }^{\mathrm{a}}$, Ahmed OUHAMMOU $^{\mathrm{c}}$, Dalila BOUSTA $^{\mathrm{a}}$ \\ a'Laboratory of Neuroendocrinology and Nutritionnel and Climatic Environment, University of Sidi Mohamed Ben Abdellah, FSDM-Fez, Morocco. \\ ${ }^{\mathrm{b}}$ Laboratory of Microbial Biotechnology. Faculty of Science and Technology, Fez Morocco. \\ ${ }^{c}$ Laboratory of Ecology and Environnemnt, (Associeted unity at STRNC-URAC 32) Faculty of Sciences Semlalia, Marrakech Morocco.
}

\begin{tabular}{|c|c|}
\hline ARTICLE INFO & ABSTRACT \\
\hline $\begin{array}{l}\text { Article history: } \\
\text { Received on: } 23 / 10 / 2016 \\
\text { Accepted on: } 18 / 01 / 2017 \\
\text { Available online: } 30 / 04 / 2017\end{array}$ & $\begin{array}{l}\text { The development of natural preservatives provides a way of substituting or decreasing the amount of synthetic } \\
\text { preservatives normally used in pharmaceutical and cosmetic products. The purpose of this research was to } \\
\text { evaluate the Silene vulgaris extract efficiency as a natural preservative in topical cream formulation. The } \\
\text { antimicrobial activity of } S \text {. vulgaris extract was assayed for determination of the minimum inhibitory }\end{array}$ \\
\hline $\begin{array}{l}\text { Key words: } \\
\text { Challenge test, reservatives, } \\
\text { Silene vulgaris, cosmetic } \\
\text { microbiological stability. }\end{array}$ & $\begin{array}{l}25^{\circ} \mathrm{C} \text { and } 37^{\circ} \mathrm{C} \text {. However the effectiveness of antimicrobial effect of extracts at concentrations }(2-20 \%) \text { in } \\
\text { topical cream was assayed by using a microbial challenge test. This test was performed following the standard } \\
\text { procedure proposed by The European Pharmacopoeia, using reference strains: Staphylococcus aureus ATCC } \\
29213 \text {, Escherichia coli ATCC } 25922 \text {, Pseudomonas aeruginosa ATCC } 27853 \text {, Candida albicans ATCC } 10231 \\
\text { and Aspergillus brasiliensis ATCC 16404. The results demonstrated that S. vulgaris extract at } 10 \% \text { and } 20 \% \\
\text { (w/w) reduced the bacteria and fungi inocula, according to the criterion A of the European Pharmacopoeia, with } \\
\text { a significant conservation during a period of } 28 \text { days compared to phenoxyethanol as a synthetic preservative. } \\
\text { Our study indicate that under the tests conditions, Silene vulgaris extract has antimicrobial activity and could be } \\
\text { considered as an alternative preservative for cosmetic formulations. }\end{array}$ \\
\hline
\end{tabular}

\section{INTRODUCTION}

Cosmetic products are subjected to microbiological contamination and spoilage. Industries have always been interested in this issue as microbial spoilage can lead to product degradation or can harm the health of the consumer and potentially spread infection in the case of pathogens and contact with injured or damaged skin. Cosmetic products must be adequately preserved during all the manufacturing process, storage and use (Rodford et al., 1997).

Preservatives are defined in the sixth amendment to the Cosmetics Directive as substances added to products for the

\footnotetext{
* Corresponding Author

Smahane BOUKHIRA, Laboratory of Neuroendocrinology and

Nutritionnel and Climatic Environment, University of Sidi Mohamed Ben Abdellah, FSDM-Fez, Morocco. Email: smahaneboukhira@gmail.com
}

primary purpose of inhibiting microorganisms from growing (Cosmetics Directive, 2009). Antimicrobial preservatives are used to reduce the likelihood of microbial growth in aqueous products and to reduce the chance of microbial survival in anhydrous products that may be contaminated during use (Baird et al., 2007). In order to evaluate the antimicrobial preservative effect of Silene vulgaris (caryophyllaceae) selected from an ethnobotanical survey realized in Sefrou region (Middle Atlas of Morocco) on our choice (Boukhira et al., 2013). S. vulgaris contains flavonoids, triterpene saponins and tannins (Boukhira et al., 2015). The Silene genus is one of the most recognized and widespread genus of Caryophyllaceae family, with more than 700 species on the earth. It has been observed that the first microbial study on Silene species in this context was carried out by Hoffman et al. in 1993, who demonstrated that Silene parishii ethanolic extract was completely effective on Bacillus subtilis, partially effective on Candida albicans, and had no effect on S. aureus and Klebsiella pneumonia. 
In addition, many researchers have been reported the antimicrobial effect of some species of Silene (Ertürk et al., 2005; Mahesh et al., 2008; Bajpai et al., 2008; Borchardt et al., 2008).

The preservatives available on the market have some degree of hypersensitivity and allergies (De Groot 1998). Efforts have been directed to the development of natural preservatives with antimicrobial properties to reduce or even replace the synthetic preservative. Among these natural compounds, plant derivatives such as extracts and essential oils (Maccioni et al. 2002; Seo et al. 2002; Nostro et al. 2004; Ostrosky et al. 2011) are widely used because of their antimicrobial activities and, therefore, have been proposed as alternative synthetic preservative agents.

Several studies demonstrated the antimicrobial activities of herbal extract and essential oil and have been proposed as natural preservatives such as Rubus rosaefolius (Ostrosky et al. 2011), tea tree (Melaleuca alternifolia), lemon grass (Cymbopogon citratus), calamint or lavender (Lavendula officinalis) (KunickaStyczyńska et al., 2011), (Calamintha officinalis) (Nostro et al., 2002) and many others.

The aim of this study is to evaluate the antimicrobial activity of Silene vulgaris extract, assessment of their efficacy as preservatives in cosmetic formulation and the evaluation of cream stability during the storage time. Preservative efficacy testing is performed to determine the type and minimum effective concentration of preservatives required to preserve the topical formulation.

\section{MATERIALS AND METHODS}

\section{Plant material}

The leaves of $S$. vulgaris (Caryophyllaceae) were collected in April 2014 from Sefrou, (Morocco). The plant was identified by Pr. A. Ouhammou and the voucher specimen (INP1206) was preserved in the herbarium of National Agency of Medicinal and Aromatic Plants Taounate-Morocco.

\section{Preparation of extract}

The dried leaves of $S$. vulgaris (20 g) were extracted with ethanol $70 \%$ using an ultrasonic bath. Sonication was performed with ultrasound frequency $35 \mathrm{KHz}, 20 \mathrm{~W}$ for $45 \mathrm{~min}$. The extract was then concentrated under vacuum in a rotary evaporator to obtain crude extract.

\section{Formulation of cream}

The cream formulation used in the preservative challenge test was prepared in our laboratory, using the raw materials described in Table 1. The challenge test was performed in six formulations: cream preserved with $2 \%(\mathrm{w} / \mathrm{w})$ of $S$. vulgaris extract (SV 2\%), cream preserved with $5 \%(\mathrm{w} / \mathrm{w})$ of S. vulgaris extract (SV 5\%), cream preserved with $10 \%$ (w/w) of S. vulgaris extract (SV 10\%), cream preserved with $20 \%$ (w/w) of S. vulgaris extract (SV 20\%), cream preserved with synthetic preservative phenoxyethanol (PH 1\%); the same cream without preservative as control group.

Table 1: The composition and $\mathrm{pH}$ of the formulation used in the challenge test.

\begin{tabular}{ccc}
\hline & Cream & Proportion (\%) \\
\hline Oily phase: & Beeswax & 22 \\
& Almond oil & 49.2 \\
& Tween 80 & 0.8 \\
\hline Aqueous phase: & Water (q.s 100) & \\
pH of the cream: & 5.6 & \\
\hline
\end{tabular}

\section{Microorganisms and microbial suspension}

The standard microbial strains procured from American Type Culture Collection (ATCC) were used in this study. The Gram-negative bacteria Escherichia coli ATCC 25922 and Pseudomonas aeruginosa ATCC 27853; Gram-positive bacteria Staphylococcus aureus ATCC 29213; yeast Candida albicans ATCC 10231 and mould Aspergillus brasiliensis ATCC 16404 were used as challenged microorganisms in preservative effectiveness test. The bacteria were cultured on Tryptic Soya Agar (TSA) at $37{ }^{\circ} \mathrm{C}$ for $24 \mathrm{~h}$, while the fungi (yeast and mould) were grown on Sabouraud dextrose agar (SDA) at $25^{\circ} \mathrm{C}$ for $48 \mathrm{~h}$ up to 5 days. For microbial inocula, the cells were harvested into $0.1 \%$ peptone water by gentle agitation and adjusted to yield

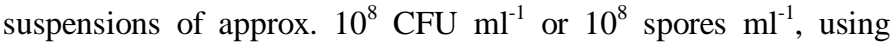
turbidimetry absorbance correlated to an aerobic plate count. The peptone water with $0.05 \%(\mathrm{v} / \mathrm{v})$ Tween 80 was used for $A$. brasiliensis harvesting

\section{Antimicrobial activity of $S$. vulgaris extract}

The minimum inhibitory concentration (MIC) was determined by the broth microdilution method (Bouhdid et al., 2009). The media were placed into each of the 96 wells of the microplates. S. vulgaris extract in water at $100 \mathrm{mg} / \mathrm{ml}$ were added into the first rows of microplates, and twofold dilutions of $S$. vulgaris extract $(100-0.097 \mathrm{mg} / \mathrm{ml})$ were made by dispensing the solutions to the remaining wells. Then, $50 \mu \mathrm{L}$ of microbial inoculum were added to each well at a final concentration of $10^{6}$ $\mathrm{CFU} / \mathrm{ml}$. The microplates were incubated at $37^{\circ} \mathrm{C}$ for $24 \mathrm{~h}$ and 48 h. The lowest concentration of the extracts that completely inhibits macroscopic growth was determined, together with the minimum inhibitory concentrations (MICs). Experiments were carried out in triplicate. Streptomycin was used as reference drugs for bacteria. The Minimal microbicidal concentration (MMC) value corresponded to the lowest concentration of extract yielding negative subcultures after incubation at $37^{\circ} \mathrm{C}$ for $24 \mathrm{~h}$ for bacteria and $48 \mathrm{~h}$ for fungi. It was determined by spreading $5 \mu \mathrm{L}$ from negative wells on Luria Bertani (LB) plates. Experiments were carried out in triplicate.

\section{Stability study of cream formulation Physical evaluation}

The color and texture of cream was determined by taking $5 \mathrm{~g}$ of cream from each set (stored at $25^{\circ} \mathrm{C}, 4^{\circ} \mathrm{C}$ and $37^{\circ} \mathrm{C}$ ) in three 
transparent glass jars and the color and texture were checked. This process was done at the time of preparation of cream (at zero time) and thereafter two weeks. $\mathrm{pH}$ of the cream was determined by using the digital $\mathrm{pH}$ meter. Prior to this, the $\mathrm{pH}$ meter was calibrated by using buffer solution of $\mathrm{pH} 3.99,7.0$ and 9.2 and then electrode was washed with de-mineralized water (Bates Roger et al., 1973). pH was checked at the time of preparation of cream (zero time) and thereafter 14 days. The creams jars stored at room temperature, $4{ }^{\circ} \mathrm{C}$ and $37^{\circ} \mathrm{C}$ were selected to check the $\mathrm{pH}$ of the cream to ensure its stability at different temperatures.

\section{Microbial control cream}

The microbial load of cream was evaluated according to Marchand et al. (2011) with some modifications. $100 \mathrm{mg}$ of cream was taken in $900 \mu \mathrm{l}$ of sterile distilled water. Then a series of dilution $\left(10^{-2}\right.$ to $\left.10^{-4}\right)$ of the creams were prepared. $100 \mu$ l of each dilution was spread on the surface of Petri dishes $(9 \mathrm{~cm})$ containing $25 \mathrm{ml}$ of TSA for bacteria or SDA for fungi. The incubation was performed at $37^{\circ} \mathrm{C}$ for $24 \mathrm{~h}$ for bacteria and at 25 ${ }^{\circ} \mathrm{C}$ for 5 days for fungi. The results are provided by $\mathrm{CFU}$ per gram of cream.

\section{Challenge test}

The formulations (20 g samples) were placed in sterile containers and separately inoculated with bacterial and fungal suspensions in order to obtain a final concentration of approximately $10^{6} \mathrm{CFU} / \mathrm{g}$. The samples were gently mixed to ensure a homogeneous microorganism distribution and incubated in the dark at $20-25^{\circ} \mathrm{C}$. After a contact time of $0,2,7,14$, and 28 days, the samples $(1 \mathrm{~g})$ were removed and placed into $9 \mathrm{ml}$ of peptone solution $0.1 \%$, and serial decimal dilutions were performed before inoculation in microbial plates. Cell viability was determined by the plate count method in TSA or SDA, and the CFU were counted after 1 or 5 days of incubation at $37^{\circ} \mathrm{C}$ and $25^{\circ} \mathrm{C}$ for bacteria and fungi, respectively. All determinations were performed in triplicate. The results were expressed as $\log \mathrm{CFU} / \mathrm{g}$. We used the dilution technique to inactivate the antimicrobial effect of the preservative. The viability and growth ability of the inoculated cells were evaluated by a growth control which consisted of $20 \mathrm{~g}$ cream base without preservative samples separately inoculated with each bacterial and fungal suspensions. In order to substantiate preservative efficacy for this type of preparation, a reduction of three $\log$ phases $(3 \mathrm{log}$ ) from the initial bacterial count within one week, and no increase thereafter up to four weeks, is necessary. For fungi, a $2 \log$ reduction within two weeks and no increase afterwards up to one month following the initial contamination is demanded according to the standards proposed by the European Pharmacopoeia Commission (E.P.) concerning topical preparations (E.P., 2005).

\section{RESULTS}

\section{Antimicrobial activity of $S$. vulgaris extract}

In the present study, antimicrobial effect of $S$. vulgaris extract was studied by using broth microdilution assay for determination of minimum inhibitory concentrations in attempt to evaluate its preservative efficacy. The minimum inhibitory concentrations of $S$. vulgaris extract against the standard organisms showed that $P$. aeruginosa and $C$. albicans exhibited a lower (MIC) than E. coli and S. aureus and A. brasiliensis (Table 2).

Table 2: Minimum inhibitory concentration (MIC) and Minimum microbicidal concentration (MMC) of S. vulgaris extract.

\begin{tabular}{lllll}
\hline & \multicolumn{2}{l}{ Silene vulgaris extract } & \multicolumn{2}{l}{ Streptomycin } \\
\cline { 2 - 5 } & MIC $^{\text {a }}$ & MMC $^{\mathbf{b}}$ & MIC $^{\mathbf{a}}$ & MMC $^{\mathbf{b}}$ \\
\hline Staphylococcus aureus & 25 & 50 & 0.004 & 0.004 \\
Escherichia coli & 25 & 50 & 0.008 & 0.064 \\
Pseudomonas aeruginosa & 3 & 12.25 & 0.032 & 0.032 \\
Candida albicans & 6 & 6 & - & - \\
Aspergillus brasiliensis & 100 & $>100$ & - & - \\
\hline MIC: minimum inhibitory & concentration & (as $\mathrm{mg} / \mathrm{ml})$. & ${ }^{\mathrm{b}} \mathrm{MMC}:$ & minimum \\
microbicidal concentration (as mg/ml), & & & \\
- : not determined.
\end{tabular}

\section{Stability study of cream formulation}

The color and texture of cream formulation was checked at the time of preparation and after 14 days period. There was found no difference in visual appearance after two week from the time of preparation. The color of cream formulation at the time of preparation and after 14 days of storage at $25^{\circ} \mathrm{C}, 37^{\circ} \mathrm{C}$ and $4^{\circ} \mathrm{C}$ was observed to be brown-green. The $\mathrm{pH}$ evaluation is important to check the stability of a cream formulation. $\mathrm{pH}$ values were not found different at all temperatures for a period of 14 days. The $\mathrm{pH}$ values after this period are 5.7 at $25^{\circ} \mathrm{C}$ and $4^{\circ} \mathrm{C}$ and 5.8 at $37^{\circ} \mathrm{C}$. Moreover, the microbial control of cream demonstrated that the total viable count for aerobic mesophylic microorganisms in cream formulation preserved with $S$. vulgaris extract at zero time and after two weeks compared to control is less than $10^{3} \mathrm{CFU} / \mathrm{g}$ of the product (Table 3) (SCCP, 2006). In addition, P. aeruginosa, S. aureus and C.albicans are not detectable in formulation.

Table 3: Microbial counts during the storage time (CFU/g)

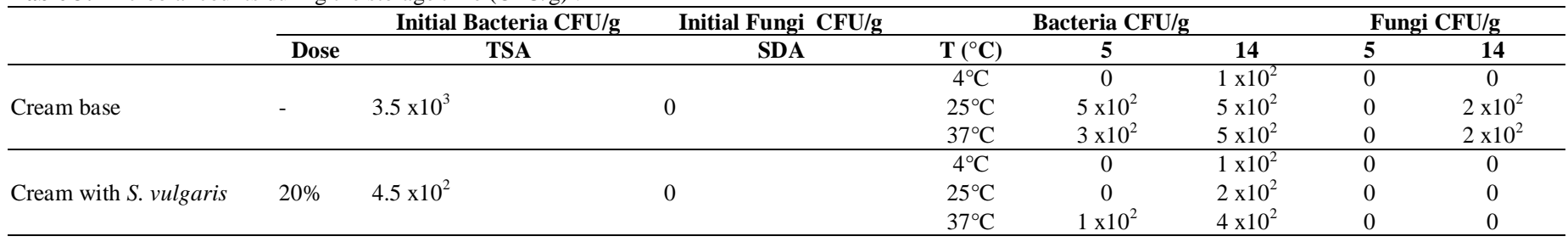



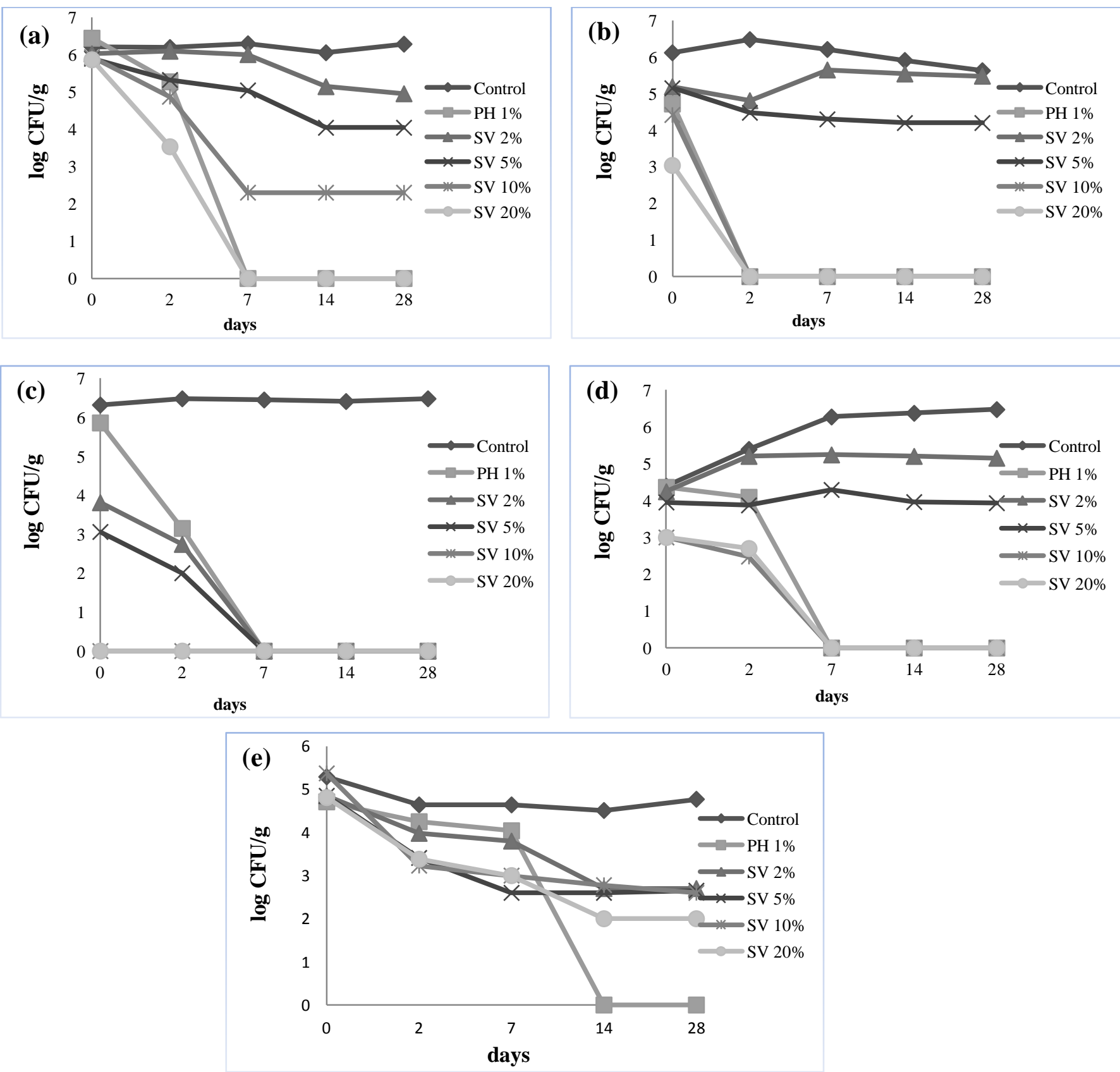

Fig. 1: The reduction of bacterial and fungal viable cells: (a) S. aureus, (b) E. coli, (c) P. aeruginosa, (d) C. albicans and (e) A. brasiliensis: SV 2\%: cream with S. vulgaris extract 2\% (w/w); SV 5\%: cream with S. vulgaris extract 5\% (w/w); SV 10\%: cream with S. vulgaris extract 10\% (w/w); SV 20\%: cream with S.

vulgaris extract $20 \%$ (w/w) PH 1\%: cream with phenoxyethanol 1\%; Control: cream without any preservative.

\section{Challenge test}

\section{Staphylococcus aureus}

The analysis of the results (figure 1a) for the bacteria showed a reduction of three logarithmic cycles in the growth for $S$. aureus in seven day and remaining unchanged until the $28^{\text {th }}$ testing day for the cream formula at the concentrations $10 \%$ and $20 \%(\mathrm{w} / \mathrm{w})$ of $S$. vulgaris extract compared to synthetic preservative phenoxyethanol $1 \%$. On the other hand the preservative at low concentration $2 \%$ and $5 \%(\mathrm{w} / \mathrm{w})$ of $S$. vulgaris extract in cream formulation was not sufficient.

\section{Escherichia coli}

Figure $1 \mathrm{~b}$ indicates the reduction of four and three logarithmic cycles in the growth for $E$. coli in 2 days, remaining unchanged until the end of the test for the cream formula at the concentrations $10 \%$ and $20 \%(\mathrm{w} / \mathrm{w})$ of $S$. vulgaris extract respectively. An immediate and persistent bactericidal effect noted from day 2 and completed by day 7 with no bacteria being recovered up to day 28 . However there was no reduction in this same period in the cream formula preserved with $S$. vulgaris extract at the concentrations $2 \%$ and $5 \%(\mathrm{w} / \mathrm{w})$. 


\section{Pseudomonas aeruginosa}

The cream formula preserved with $S$. vulgaris extract at studied concentrations (2-20\%) showed a antimicrobial action which satisfied the E.P. criteria A against P. aeruginosa. The cream showed an immediate and persistent bactericidal effect, noted from day 0 and completed by day 2 with no bacteria being recovered up to day 28 in compared to phenoxyethanol $1 \%$ (Figure1c).

\section{Candida albicans}

Figure 1d indicates the reduction of three logarithmic cycles in the growth for Candida albicans in 14 days, remaining unchanged until the end of the test. The formulation at 10 and $20 \%$ (w/w) of $S$. vulgaris extract exhibited an antimicrobial action which satisfied the E.P. criteria. However there was no reduction in this same period in the cream formula at the concentrations $2 \%$ and $5 \%(\mathrm{w} / \mathrm{w})$.

\section{Aspergillus brasiliensis}

Figure 1e presents the reduction of two logarithmic cycles in the growth for $A$. brasiliensis in $14^{\text {th }}$ day, remaining unchanged until the end of the test for cream formula. The extract of $S$. vulgaris at studied concentrations examined in the present formulation succeeded in satisfying the A criteria of the E.P. for preservative efficacy.

\section{DISCUSSION}

Preservatives are ingredients used to limit microbial growth and survival by exerting adverse effects upon various biological and cellular processes in contaminating microorganisms. In our research, $S$. vulgaris extract was found to be active against Gram-negative bacteria $P$. aeruginosa and the yeast $C$. albicans, at the concentrations $3 \mathrm{mg} / \mathrm{ml}$ and $6 \mathrm{mg} / \mathrm{ml}$ respectively, whereas the extract was less active against $E$. coli and $S$. aureus at $25 \mathrm{mg} / \mathrm{ml}$ of MIC values. This results of MICs is in accordance with the previous studies that reported that the minimum inhibitory concentrations of some herbal extracts showed that $P$. aeruginosa exhibited lower (MIC) than $S$. aureus (Gislene et al., 2000; Biyiti et al., 2004; Suffredini et al., 2006; Esra et al., 2012; Sthéfane et al., 2014; Onivogui et al., 2015).

Gattoa et al. (2011) reported that $S$. vulgaris extract contained flavone apigenin derivatives evaluated by Highperformance liquid chromatography HPLC. In addition several flavonoids including apigenin, flavones have been shown to possess potent antibacterial activity (Cushnie et al., 2005). Another study of Sato et al. (2000) reported that flavones derivative inhibited the growth of $S$. aureus.

Related to the microorganisms used during the test, it must be guaranteed that they have been challenged against the preservative system for 28 days to substantiate the results of the experiments. Thus, the control was used to prove the viability of the inoculated cells and their growth ability during the test period (Figure 1). The microbial challenge test performed in topical cream formulation preserved with $S$. vulgaris extract at the concentrations $10 \%$ and $20 \%$ (w/w) has satisfied the criteria for microbial effectiveness compared to synthetic preservative phenoxyethanol at $1 \%$, considering the official criteria of European Pharmacopoeia (E.P., 2005). The preservative in the assayed cream was found particularly effective against Gramnegative strains, presenting a lethal effect at 2 days for $E$. coli and at day 0 for $P$. aeruginosa after inoculation.

The result of the challenge test performed in the cream preserved with $5 \%(\mathrm{w} / \mathrm{w})$ of $S$. vulgaris extract for S. aureus and $E$. coli, did not comply with the criteria of European Pharmacopoeia due to there being $0.85 \mathrm{log}$ reductions in both stains on the seventh day and 1.85 and $0.95 \log$ reductions respectively on the 14th day. This result is due to the used preservative concentration, as well as the reduction of its available concentration resulting from an interaction with the formulation components or a resistant microorganism selection (Bloomfield et al., 1988).

On the other hand, the preservative efficacy against $P$. aeruginosa and $A$. brasiliensis was much sufficient in cream formula preserved with $S$. vulgaris extract at $2 \%$ and $5 \%(\mathrm{w} / \mathrm{w})$ concentration. According to Griffin et al., (1994), the optimum $\mathrm{pH}$ for the development of different fungi lays in the range between 4.0 and 6.0. The $\mathrm{pH}$ of the prepared creams lies in the range of 5.75.8 which provides a favorable environment to fungi growths. The $S$. vulgaris extract antimicrobial action at all concentrations studied except for C. albicans at $2 \%$ and $5 \%(\mathrm{w} / \mathrm{w})$, did not comply with the criteria of European Pharmacopoea.

In addition to this study we have compared the preservative efficacy of $S$. vulgaris extract with other plant extracts such as essential oil of Origanum elongatum and Thymus broussonitii in the prepared cream (data not publuished). We demonstrated that $S$. vulgaris extract was significant preservation during a period of 28 days against the five reference strains ( $S$. aureus, E. coli, P. aeruginosa, C. albicans and A. brasiliensis) recommended by the European Pharmacopoeia compared to the essential oils of Origanum elongatum, Thymus broussonitii and to phenoxyethanol as a synthetic preservative.

In others studies, Seo et al. (2002) developed a preservative system that consisted of a mixture of chitosan and Inula helenium extract at $10 \%(\mathrm{w} / \mathrm{w})$. These results presented an excellent antimicrobial effect in cosmetic formulations against strains of A. niger, C. albicans, E. coli, P. aeruginosa and $S$. aureus. In our study, the extract of $S$. vulgaris at concentrations of 10 and $20 \%$ (w/w) was effective against the tested gram negative and gram positive bacteria and fungi and present an interesting bactericidal effect against $P$. aeruginosa Gram-negative in all concentrations up to $2 \%(\mathrm{w} / \mathrm{w})$.

\section{CONCLUSION}

The development of natural preservatives provides a way of replacing or reducing the amount of synthetic preservatives normally used in cosmetic preparations. In addition, these agents 
have less toxic effects and represent a possible natural and safer alternative of the preservatives. Our study demonstrated that $S$. vulgaris extract at concentrations of $10 \%$ and $20 \%(\mathrm{w} / \mathrm{w})$ inhibit the growth of microorganisms effectively as that of phenoxyethanol in cream formulation. Therefore, it can be recommended as effective candidate for natural cosmetic preservatives in the assayed topical cream. That preservative effect was maintained during 28 days, and satisfying the antimicrobial effectiveness test criteria of the European Pharmacopoeia.

\section{ACKNOWLEDGMENTS}

Financial support and sponsorship: This work was supported by FP7-CINEA and BMO/A710- SN2012-049-PCSI "Projet de Coopération Scientifique Inter-Universitaire”.

Conflict of Interests: There are no conflicts of interest.

\section{REFERENCES}

Pharmaceuticals.

Baird RM. 2007. Guide to Microbiological Control in

Bajpai VK, Shukla S, Kang SC. Chemical composition and antifungal activity of essential oil and various extract of SilenearmeriaL. BioresourceTechnol, 2008; 99: 8903-8908.

Practice.Wiley.

Bates Roger G. 1973. Determination of $\mathrm{pH}$ : Theory and

Bernatoniene J, Masteikova R, Davalgiene J, Peciura R, Gauryliene R, Bernatoniene R, Majiene D, Lazauskas R, Civinskiene G, Velziene S, Muselik J, Z. Chalupova. Topical application of Calendula officinalis(L.): formulation and evaluation of hydrophilic cream with antioxidant activity. J Med Plant Res, 2011; 5: 868-877

Biyiti LF, Meko'o DJL, Tamzc V, Amvam ZPH. Recherche de l'Activité Antibactérienne de Quatre Plantes Médicinales Camerounaises. Pharm Med TradAfr Val, 2004; 13: 11-20.

Bloomfield SF. Control in microbial contamination in nonsterile pharmaceuticals, cosmetics and toiletries 1988. In: Bloomfield SF, Baird R, Leal RE, Leech R, editors. Microbial quality assurance in pharmaceuticals, cosmetics and toiletries. Chichester: Ellis Horwood 9-14.

Borchardt JR, Wyse DL, Sheaffer CC, Kauppi KL, Fulcher RG, Ehlke NJ, Biesboer DD and Bey RF. Antimicrobial activity of native and naturalized plants of Minnesota and Wisconsin. J Med Plants Res, 2008; 2: 98-110.

Bouhdid S, Abrini J, Zhiri A, Espuny MJ, Manresa A. Investigation of functional and morphological changes in Pseudomonas aeruginosa and Staphylococcus aureus cells induced by Origanum compactum essential oil. J ApplMicrobiol, 2009; 106: 1558-1568.

Boukhira S, Bousta D, El Mansouri L, Nordine A, Hamsas El Youbi A, Daoudi A. Antioxidant activity and protective effect on dna damage and deoxyribose of Silene vulgaris (moench) garcke from Morocco. Int J Pharmacogn and Phytochemical Res, 2015; 7: 1172-1178.

Boukhira S, EL Mansouria L, Bousta D. Ethnobotanical studies of some medicinal and cosmetic plants used in the province of Sefrou, Middle Atlas of Morocco. J Ethnobiology Trad Med, 2013; 120: 661-670.

Cosmetics Directive. 2009. The European Commission, 6th Amendment, (EC) No 1223/2009.

Cushnie TPT, Lamb AJ. Antimicrobial activity of flavonoids. Int J Antimicrobial Agents, 2005; 26: 343-356.

Cyrus WG, Gakuya WD, Nanyingi MO, Njonge FK, Mbaria JM. Antibacterial and cytotoxic activity of Kenyan medicinal plants. Mem Inst Oswaldo Cruz, Rio de Janeiro, 2008; 103: 650-652.

De Groot AC. Fatal attractiveness: the shady side of cosmetics. ClinDermatol, 1998; 16:167-169.
Ertürk O, Katı H, Yaylı N and Demirbag Z. Antimicrobial Properties of Silenemultifida (Adams) Rohrb. Plant extracts. Turkish J Biol, 2005; 30: 17-21.

Esra MMA, Aisha ZIA, Salwa MEK, Umelkheir MAG. Antimicrobial Activity of Cannabis sativa L. Chinese Med, 2012; 3: 6164.

European Pharmacopoeia Commission 5.0 (E.P. 5.0). 2005. Efficacy of Microbial Preservation, Group of Experts no. 1CM (Microbial Contamination). Strasbourg: Council of Europe.

Gattoa MA, Ippolito A, Linsalata V, Cascarano NA, Nigro F, Vanadia S, Di Venere D. Activity of extracts from wild edible herbs against postharvest fungal diseases of fruit and vegetables. Postharvest Biology and Technol, 2011; 61: 72-82.

Gislene GFN, Locatelli J, Freitas PC, Silva GL. Antibacterial activity of plant extracts and phytochemicals on antibiotic resistant bacteria. Braz J Microbiol, 2000; 31: 247-256. New York

Griffin DH. 1994. Fungal Physiology, 2nd edn. Wiley-Liss,

Hoffmann JJ, Timmermann BN, Mclaughlin SP, Punnapayak H. Potential antimicrobial activity of plants from the Southwestern United States. Int J Pharmacog, 1993; 31: 101-115.

Kunicka-Styczyńska A, Sikora M and Kalemba D. Lavender, tea tree and lemon oils as antimicrobials in washing liquids and soft body balms. Int J CosmetSci, 2011; 33: 53-61.

Maccioni AM, Anchisi C, Sanna A, Sardu C, Dessi S. Preservative systems containing essential oils in cosmetic products. Int J CosmetSci, 2002; 24: 53-59.

Mahesh B and Satish S. Antimicrobial activity of some important medicinal plant against plant and human pathogens. World $\mathrm{J}$ AgrSc, 2008; 4: 839-843.

Manou I, Bouillard L, Devleescherouwer MJ, Barel AO. Evaluation of the preservative properties of Thymus vulgaris essential oil in topically applied formulations under a challenge test. J ApplMicrobiol, 1998; 84:368-378.

Marchand G, Barrette MC, Lesage J, Larue M. 2011. laboratory methods, enumeration of culturable bacteria and mold from the air taken from polycarbonate filter. Posted by IRSST.

Nostro A, Cannatelli MA, Morelli I, Cioni PL, Bader A, Marino A and Alonzo V. Preservative properties of Calamintha officinalis essential oil with and without EDTA. Lett ApplMicrobiol, 2002; 35: 385 389.

Nostro A, Cannatelli MA, Morelli I, Musolino AD, Scuredi F, Pizzimenti F, Alonzo V. Efficiency of Calamintha officinalis essential oil as preservative in two topical product types. J ApplMicrobiol, 2004; 97: 395-401.

Onivogui G, Diaby M, Chen X, Zhang H, Kargbo MR, Song Y. Antibacterial and antifungal activities of various solvent extracts from the leaves and stem bark of Anisophyllealaurina R. Brex Sabine used as traditional medicinein Guinea. J Ethnopharmacol, 2015; 168: $287-$ 290.

Ostrosky EA, Maria E, Marcondes C, Nishikawa SDO, Lopes PS, Henrique G, Kaneko TM. Rubusrosaefolius Extract as a Natural Preservative Candidate in Topical Formulations. AAPS Pharm Sci Tech, 2011; 2: 732-737.

Rauha JP, Remes S, Heinonen M, Hopia A, Kahkonen M, Kujala T, Pihlaja K, Vuorela H, Vuorela P. Antimicrobial effects of Finnish plant extracts containing flavonoids and other phenolic compounds. Int J Food Microbiol, 2000; 56: $3-12$.

Rodford R. Safety evaluation of preservatives.Int J Cosmetic Sci, 1997; 19: 281-290.

Sato Y, Suzaki S, Nishikawa T, Kihara M, Shibata H, Higuti T. Phytochemical flavones isolated from Scutellariabarbata and antibacterial activity against methicillin-resistant Staphylococcus aureus. J Ethnopharmacol, 2000; 72:483-488.

SCCP. 2006. The SCCP's notes of guidance for the testing of cosmetic ingredients and their safety evaluation. 6th revision December link. 
Seo SB, Ryu CS, Ahn GW, Kim HB, Jo BK, Kim SH, Lee JD and Kajiuchi T. Development of a natural preservative system using the mixture of chitosan-Inulahelenium L. extract. Int $\mathrm{J}$ of cosmetic Sc, 2002; 24: 195-106.

Sthéfane GA, Lucas FA, Maria EAP, Graziela TO, Ezequias PS, Rosy IMAR, Jaqueline MSF, Luciana ARSL. Volatile compounds of Lamiaceae exhibit a synergistic antibacterial activity with streptomycin. Braz J Microbiol, 2014; 45: 1341-1347.

Suffredini IB, Paciencia MLB, Nepomuceno DC, Younes RN, Varella AD. Antibacterial and cytotoxic activity of Brazilian plant extracts Clusiaceae. Mem Inst Oswaldo Cruz, 2006; 101: 287-290.

\section{How to cite this article:}

Boukhira S, Balouiri M, El Mansouri L, El Youbi Ae, Bouarfa M, Lebtar S, Ouhammou A, Bousta D. Development of Natural Preservative from Silene vulgaris Extract in Topical Formulation under a Challenge Test and its Stability Study. J App Pharm Sci, 2017; 7 (04): 142-148. 